\title{
Analitycal Review on Logo Redesign GO-JEK Group in Creating Brand Company Image
}

\author{
$1^{\text {st }}$ Intan Primasari \\ Department Midwifery \\ Dept. of Science Communication \\ Faculty of Science Communication and \\ Humanities \\ Universitas Muhammadiyah Bandung, \\ Jln. Soekarno Hatta No. 752, \\ Panyileukan Kota Bandung \\ primasari.intan@gmail.com
}

\author{
$2^{\text {nd }}$ Agung Tirta Wibawa \\ Department Midwifery \\ Dept. of Science Communication \\ Faculty of Science Communication and \\ Humanities \\ Universitas Muhammadiyah Bandung, \\ Jln. Soekarno Hatta No. 752, \\ Panyileukan Kota Bandung
}

\begin{abstract}
The highly competitive environment forced their brands to develop strategy to maintain their brand positioning. In order for a brand to competitive advantage in the market, one of the elements that need to be achieved is not only product quality and marketing strategy but also positive brand image from customer's perspective. To create a positive brand image, one of the strategy that can be implemented is rebranding. Some of changes within rebranding is the change of the name, logo and tagline. Rebranding strategy had been implemented by some of big companies in Indonesia namely GO-JEK Group. GO-JEK Group had changed their corporate logo by changing the elements on the logo comprising emblem, color, and font. From this phenomena the researcher will conduct a research titled Analytical Review on Logo Redesign GO-JEK Group in Creating Brand Company Image. Methodology of research is study case with brand image theory approach, community relationship and logo redesign and rebranding. The purpose of this research is to study wheter the logo redesign can create a positive brand image.
\end{abstract}

\section{Keywords-Logo Redesign, Go-Jek, Brand, Company}

\section{INTRODUCTION}

Image is one of the most important assets for a company that is supposed to be constantly elevated and maintained. A good image is an imperative tool not only to attract consumer in choosing a product or a service but also to improved consumer's satisfaction towards the organization. It is closely related with public or wide audience. Their particular impression and their knowledge about the organization will establish the image of the organization. According to Kazt (Soemirat and Ardianto 2005:78), an image is the way of other parties create their perception towards a company, someone, a committee or an activity. Image also show organizations their existence in public's eyes in which express the society's view towards the organization that is shaped in the long run.

A good image will give impact on accomplishment of the goals that was set by an individual or an organization.
In this case, an image is capable to give opportunity for the company to gain profitability from the product or services that was offered. On the other hand, a good image will also boost public's trust towards the organization in performing its business operation because to build a good image required significant capital to be spent by the organization.

\section{RESEARCH METHODOLOGY}

Methodology of research is study case with brand image theory approach, community relationship and logo redesign and rebranding. Holistically and by way of description in the form of words and language in a special natural context and by utilizing various natural methods.

\section{RESULTS AND DISCUSSION}

Henceforward, every organization always thrive to build positive image in the eyes of their consumers. Positive image is imperative to be constantly shaped and maintained for the longevity of the organization. Shaping an image has a purpose to evaluate policy and to resolve any misconception. In building or shaping an image it requires a rigid and long process because it is based on different set of information received by an individual. Building positive image of an organization is closely tied to perception, belief, and society's opinion toward the organization itself. There are five factors in shaping organization's image:

- Physical Identity: Objects that can be observed visually (organization's name, logo, text, font selection, color, building, office lobby), audio (organization's jingle), media communication (company profile, brochure, leaflet, yearly reports, dan media reports).

- Non Physical Identity: Observed through organization's history, philosophy, trust, value, and culture. 
- Management: vision, mission, system, policy, rules, procedure's flow, technology, human resources, organization strategy, job design, service system, and product positioning.

- Result Quality: Product and service's excellence.

- Activity and Relationship Pattern: Rated from the organization or company's relationship with the public, corporate social responsibility, quality of communication, customer's experience, and communication network.

Facing a very competitive market each company have their own strategy to be able to sustain their business. One of the management's strategy to gain leverage is by implementing a change in the company's identity. As stated by Ardianto (2011: 62), company's identity mostly become an important factor in assuring the smoothrunning of product creation. It goes even as far as that it is also capable to influence buying decision because the company's identity in the form of its name or logo can be pivotal factor of a sale of a product, as from it the consumer's may know the producer of that particular product or services that they bought.

Among company's identity that has essential factor in the company's strategy is logo. According to Paul A. Argenti, beside the name, logo is a key element of an organization's identity (Argenti, 2010: 78). Logo is an important element of an identity. This also sets as background by the people who made initial contact with a company through logo, with advertising from various media (television, radio, print media, and internet), letter, product packaging and etc. As part of identity implementation, company's logo become the base foundation because logo is designed as an emblem or a special symbol to give that particular company special distinction from the other companies.

If a company was likened as a human then it is definitely has its own individual character, cultures, and values. Logo as its face, visual identity made them more human by giving its face and character in the form of a logo (Rustan, 2009; 66). Wide audience or society in general associate logo and build their perception towards the company through it. The shape of a logo can be in the form of certain symbols, such as picture, shape, special letters, or phrase that was written with specific typeface that reflects on the company's personality.

GO-JEK Group strengthen its position as a forefront technology platform in South East Asia, pride of Indonesian, through its rebranding including redesigning their logo that was announced on July 22, 2019 in Jakarta. This rebranding become a history milestone that marks the evolution of GO-JEK Group from ride hailing to become a new integrated ecosystem in the movement of people, objects as well as electronic financial payment gateway.

"All the accomplishment of GO-JEK Group since our application platform was launched five yeards ago is an evidence of our partners, consumers, business partners, and investors' trust towards our vision and business model that we developed. We will not be here today without the support of our million partners and their families, as well as our millions of consumers that has always trust us to help them providing service for their daily needs in Gojek platform", said Kevin Aluwi, Co-Founder GO-JEK Group in a press conference for the logo redesign.

"Gojek has grown exponentially since our application was launched. From June 2016, to June 2019, the number of processed transaction in our platform has jumped to $1.100 \%$ or 12 times. This significant growth was pushed by the increased in consumers demand on intregrated services provided by Gojek", said Kevin. Gojek started by only 20 driver partners to now 2 million driver partners, 400 thousands merchant partner and 60 thousands service providers throughout South East Asia.

Gojek, had evolved from a call center to its technology ecosystem that offer smart way to reduce the hassle that society face in daily life. "We use the technology, date and our understanding of the market that we operates to present an innovation and opportunity for all parties within our ecosystem to enhance their lives. We are optimizing our product and service as well as personalizing it based on each consumer's preferences. At the moment within our ecosystem there are three super applications that are meticulously connected to help consumers, partners, and merchants" said Kevin.

In the consumer's application, whereas from the start has only 3 services now has evolved to 22 services on demand for numerous needs. Gojek has even become a new social platform as it introduced its own chat features among Gojek users since last April. Furthermore, Gojek consumer now can easily gave tip to the driver partner through cashless basis. Total tip that was given through Gojek application now reached Rp 285 Billion.

In the partner's application, Gojek has also evolved to not only an order processing application but also providing access on financial features as well as safety and security for the partners.

In the merchant application, Gojek platform had evolved to become a digital asset for business expansion and competitive advantage. "The technology that we offer to the merchant simulate an upstream and downstream business flow. We offer a solution for market expansion through GoFood, hassle-free payment, inventory, point of sale and the flexibility for the merchants to promote their special offers", said Kevin.

"As a platform of more than twenty on-demand services, millions of our driver partners and merchants, as well as millions of consumers, there are many factors to be consider to balance their needs. In order for us to guarantee the best experience, Gojek constantly use the latest technology including machine learning and artificial intelligence to build smart allocation system. This smart allocation system enables us to gain significant impact in terms of driver and consumer's experience, from the reduction of number in cancellation to utilization, as well as increasing dispatch time.

Andre Soelistyo, President of GO-JEK Group in the same opportunity also stated that advance technology and ecosystem business model that is developing in Gojek made the application continuously lead in the Indonesian market - the biggest market in South East Asia. "We 
started the service by ride-hailing but within short period of time, we had evolved to become the industry leader with transportation services, food delivery services, digital payment, logistics, as well as merchant services", said Andre.

From the data that was sourced from Nikkei, Japanese media, indicated that the number of active users of Gojek in Indonesia is far more high than any other on demand application. The same data also specified that the number of active monthly users of Gojek in Indonesia is equal to the number of active monthly users of the biggest ride sharing application in world, located in United States of America. This data also backed by the recent survey done by Alvara Research Center that stipulate the three services of Gojek in which transportation, food delivery and digital payment become the preference of millennial generation in Indonesia.

"Not only in Indonesia but also other countries where we expand and operate, Gojek had received a warm welcome. Our decision to combine Gojek technology with in-depth knowledge from the local team approved to be a success. In Vietnam, Thailand and Singapore our presence is highly long awaited from the consumer and driver partner because it gives them more options", said Andre.

Nadiem Makariem, Founder and CEO of GO-JEK Group stated, "The presence of this new logo was inspired by the journey of Gojek that had been successful to become the leader of an advance technology platform in South East Asia. This new logo represents the main reason why Gojek was created, to solve problems using technology."

"This logo symbolize one button for all. On the other side, the new circle in the new logo design represent our Gojek as an ecosystem that becoming more solid and cohesive in giving the benefits for all. This new logo embody our thrive to relentlessly offer smart ways in resolving challenges that are being faced by our consumers to live their daily life more convenient, as the new source of income for our partners, for opportunity to grow their businesses for our merchants and many more. We are currently promoting our own hasthtag \#PastiAdaJalan, to capture the mentioned points", said Nadiem.

On top of that, the new logo puts the partners in special positon. For example, this logo was adapted from the driver icon that is the symbol for the Go-Ride service in Gojek application. "We are proud of our Gojek partners that are growing together with the advancement of technology hence they are reliable and contribute to community, whenever and wherever they needed. They are also have an active role in stimulating the growth of digital economy by assisting the daily life of millions of our consumers", continue Nadiem.

The bravery of Gojek reflect in their new breakthrough of transforming the services they provided. Gojek logo used to emanate from the concept of motorcycle ride hailing application hence the logo was symbolize by a motorcycle being ridden. The redesign of the logo made it more simplified as to show the more range of services they provide.

\section{CONCLUSION}

These rebranding activities deemed as the company trying to reshape its image in pursuance of elevating Gojek to company that provides various services and reach wider market. It can be assumed that the previous logo made Gojek's image as a motorcycle ride hailing only.

Henceforth, the logo was redesigned to become a button symbol that was circled by protective lines, interpreting the will of Gojek to place its partners in its core of business. In addition, the new logo also illustrate a protective helmet in which mean that Gojek still portraying its initial identity as various delivery services using motorcycle as the medium. This transformation show the level of Gojek in terms of its company development which is innovative by providing new services as well other features that supported its user in experiencing the benefit of Gojek's new branding.

\section{REFERENCES}

[1] Ardianto, Soemirat Soleh Prof, DR, M.S, "Dasar - Dasar Public Relation," PT. Remaja Rosdakarya.

[2] Ardianto, "Handbook of Public Relations," Simbiosa Rekatama Media

[3] Argenti, Paul, "Komunikasi Korporat terjemahan Putri Aila Idris" Salemba Humanika

[4] Kotler, dan Amstrong, "Principles Of Marketing, Global Edition, 14 Edition". England:Pearson Education.

[5] Kotler, dan Keller, "Marketing management. 14 E Edition". England :Pearson

[4] Rustan, Surianto, "Mendesign Logo", PT. Gramedia Pustaka Utama

[5] www.gojek.com 